УДК 37.014.3:373.5.011.33(477)“20”

DOI:

Алла Загородня, доктор педагогічних наук, доцент, провідний науковий співробітник відділу історї та філософії освіти Національної академії педагогічних наук України

\title{
СТАНДАРТИЗАЦІЯ ПРОФІЛЬНОГО НАВЧАННЯ В УКРАЇНІ (2011-2017)
}

Стаття присвячена вивченню теоретичних і практичних аспектів досвіду стандартизації профільного навчання в Україні у 2011-2017 рр. ХХІ ст. Окреслено ключові орієнтири щодо стандартизачії профільного навчання, які представлені у нормативно-правових документах. Зосереджено увагу на основних соціальноекономічних проблем, що відбувалися в 2011-2017 рр., і мали вплив на процес стандартизації профільного навчання старшокласників. Подано авторське визначення поняття “профільне навчання". Схематично унаочнено алгоритм поетапного запровадження досвіду стандартизації профільного навчання в Україні у 2011-2017 рр. ХХІ ст. Проаналізовано перспективні напрями стандартизації профільного навчання в Україні.

Ключові слова: нормативні документи; профільне навчання; стандартизачія; икільна освіта

Puc. 1. Jim. 10.

Alla Zahorodnia, Doctor of Sciences (Pedagogy), Associate Professor, Leading Researcher of the History and Philosophy of Education Department,

The National Academy of Pedagogical Sciences of Ukraine

\section{STANDARDIZATION OF PROFILE EDUCATION IN UKRAINE (2011-2017)}

The article is devoted to the study of theoretical and practical aspects of the experience of standardization of specialized education in Ukraine in 2011-2017 of the XXI century. The key guidelines for standardization of specialized education, which are presented in legal documents, in particular: State standard of basic and complete general secondary education (2011); Order "On approval of the Concept of specialized education in high school"; "The concept of specialized education in high school" (2013); "The concept of the New Ukrainian School" (2016); updated version of the Law of Ukraine "On Education" (2017), etc. The focus is on the main socio-economic problems that occurred in 2011-2017, and had an impact on the process of standardization of specialized education of high school students, in particular: convince that the problem of standardization of specialized education, in particular lack of information on specialized education standards and continuity between specialized seniors school and other vocational and higher education institutions; outdated material and technical base; imperfection of qualification characteristics for professions and types of work, which would be supported by legal documents that clearly regulate "licenses to conduct certain practices" and determine whether a certain person can engage in a particular activity. The author's definition of "profile education" is given, which is considered as a type of differentiated education, which takes into account the educational needs, inclinations and abilities of students and creates conditions for high school students to study according to their professional self-determination. The main tasks of specialized training are outlined. The algorithm of gradual introduction of the experience of standardization of profile education in Ukraine in 2011-2017 of the XXI century is schematically illustrated. Perspective directions of standardization of profile education in Ukraine are analyzed, which contribute to the real construction of each high school student's own educational trajectory in accordance with the Ministry of Education of Ukraine adopted for all these years.

Keywords: profile training; regulatory documents; standardization; school education.

П остановка проблеми. Глобальні тенденції в освіті XXI ст. актуалізують питання стандартизації профільного навчання та зосереджують увагу на політичних аспектах роботи над кваліфікаціями, що впливає на посилення прогнозованості розвитку профільного навчання в Україні, а саме розробку професійних стандартів, які відображені у нормативних документах, що мають визначати обсяг навчальних предметів, їх погодинне навантаження та за кожним окремим навчальним планом, інформацію про профілі та зміст певного типу професії, систему показників у вигляді компетентностей для різних кваліфікаційних рівнів й давати змогу встановити ступінь відповідності професійної діяльності майбутніх фахівців загальним вимогам сучасного ринку праці.

Загострення у 2011-2017 рр., деяких соціальноекономічних проблем переконують, що проблема стандартизації профільного навчання, зокрема фахової перед вищої освіти, в Україні була і досі $€$ вкрай актуальною 3 декількох вагомих причин. Серед яких найголовнішою $є$ хибні умовиводи через нестачу інформації про стандарти профільного навчання та наступність між профільною старшою школою та іншими 
професійно-технічними та вищими закладами освіти. Слід також звернути увагу на застарілу матеріально-технічну базу, недосконалість кваліфікаційних характеристик на професії та види робіт, які були б підкріплені нормативно-правовими документами, що чітко регламентують “ліцензії на ведення певної практики” та визначають, чи може певна особа займатися конкретним видом діяльності.

Проблема стандартизації профільного навчання в шкільній освіті України була і досі залишається предметом досліджень багатьох науковців, зокрема: С. Гончаренка, Г. Селевка, П. Сікорського (термінологічнеполепрофільногонавчання); О.Бугайова, Н. Ничкало, І. Унта, О. Ярошенка (вивчення рівнів, форм і видів профільного навчання); Г. Авчіннікова, О. Барановська, Г. Васьківська, С. Дятленко, С. Закірова (диференціація змісту навчання школярів та профільна підготовка); державна освітня політика щодо організації профільного навчання й змісту шкільної освіти в радянській Україні (Л. Березівська); соціально-професійний вибір учнів (M. Піддячий); затвердження стандартів профільного навчання (Г. Васьківська, Ю. Грегоращук, В. Кушнір) та ін.

Мета статті полягає у вивченні теоретичних і практичних аспектів досвіду стандартизації профільного навчання в Україні у 2011-2017 pp. XXI cт.

Теоретичною i методичною основою дослідження є системний підхід до вивчення фундаментальних положень стандартизації профільного навчання в України. Для розв'язання поставлених завдань використано такі загальнонаукові методи, як: 1) метод аналізу та синтезу ( 3 метою розкриття понятійнокатегоріального апарату дослідження); 2) наукової абстракції, індукції та дедукції (при узагальненні вітчизняного досвіду стандартизації профільного навчання); 3 ) абстрактно-логічний (для теоретичного узагальнення результатів дослідження та формулювання висновків). Спеціальні методи: 4) ранжирування, шкалювання, реєстрації, систематизації та диференціація, угруповання, графічного вираження даних.

Для розв'язання проблеми нашого дослідження методологічно важливе психолого-педагогічне осмислення ключового поняття. У такий спосіб для операціоналізації поняття “профільне навчання" вважаємо за доцільне спиратися на таке його визначення: "Профільне навчання" - вид диференційованого навчання, який передбачає врахування освітніх потреб, нахилів та здібностей учнів і створення умов для навчання старшокласників відповідно до їхнього професійного самовизначення, що забезпечується за рахунок змін у цілях, змісті та структурі організації навчання [4, 31].

Серед завдань профільного навчання слід розрізняти такі: створення умов для врахування й розвитку навчально-пізнавальних і професійних інтересів, нахилів, здібностей і потреб учнів старшої школи в процесі їхньої загальноосвітньої підготовки; виховання в учнів любові до праці, забезпеченні умов для їхнього життєвого і професійного самовизначення, формування готовності до свідомого вибору й оволодіння майбутньою професією; формування соціальної, комунікативної, інформаційної, технічної, технологічної компетенцій учнів на допрофільному рівні, спрямування підлітків щодо майбутньої професійної діяльності; забезпечення наступноперспективних зв'язків між загальною середньою і професійною освітою відповідно до обраного профілю [3, 18; 5, 128].

Як відомо, в листопаді 2011 р. затверджено новий Державний стандарт базової і повної загальної середньої освіти, основні положення якого стосовно старшої школи набували чинності 31 вересня 2018 р. Ключовими орієнтирами означеного стандарту є: повага до особистості учня та визнання пріоритетності його інтересів над набуттям суто теоретичних знань без їх практичного застосування; визнання важливості становлення вільної від радянських стереотипів особистості, підтримка самостійності учнів, їх власного вибору, досвіду, прагнень, пізнавального інтересу та наполегливості; розвиток критичного мислення, а також створення гармонійних умов на засадах чесності, милосердя, доброти, справедливості, співпереживання, взаємоповаги і взаємодопомоги, поваги до прав і свобод людини для його реалізації; забезпечення рівних можливостей кожного учня до здобуття освіти без будь-яких форм дискримінації учасників освітнього процесу; формування в учнів патріотизму та активної громадянської позиції, плекання любові до рідного краю, відповідального ставлення до довкілля.

Згідно $з$ оновленим Державним стандартом базової і повної загальної середньої освіти (2011), базова середня освіта матиме такі цикли, як адаптаційний (5-6 класи) та базового предметного навчання (7-9 класи), що дають змогу враховувати вікові й індивідуальні особливості розвитку і потреби учнів, а також забезпечити просування індивідуальними освітніми траєкторіями [2].

У зв'язку з необхідністю створення умов для реального втілення ідеї профільного навчання у 
старшій школі Базовим навчальним планом оновленого освітнього стандарту (2011) цілком обгрунтовано передбачено зменшення кількості тижневих годин для реалізації інваріантного складника змісту освіти до 18 год., що становить $54 \%$ гранично допустимого тижневого навчального навантаження старшокласників. 3 огляду на це передбачений стандартом зміст освіти вимагає перегляду з позицій урахування мети і завдань профільного навчання та співвіднесення його обсягу з часом, що відводиться на засвоєння цього змісту [1].

Прийнята в 2013 р. “Концепція профільного навчання старшокласників”, задекларувала новий зміст їх профільного навчання за рахунок змін у структурі, змісті й організації освітнього процесу, що надало можливість повніше враховувати інтереси, нахили і здібності учнів, їх можливості, створити умови для навчання відповідно до їхніх освітніх і професійних інтересів [9].

У 2014 р. керівництво МОН заявило про намір здійснити перехід до 12-річної загальної середньої освіти 3 такою структурою: 5 років - початкова школа, 4 роки - основна середня школа, 3 роки старша (профільна) школа.

Означене стало поштовхом до перебудови системи шкільної освіти, і знайшло віддзеркалення у прийнятті “Концепції Нової Української школи” (2016), яка структурувала профільну середню школу у два цикли навчання: 10 клас (1 цикл навчання), 11-12 класи (2 цикл), що загалом займає 3 роки навчання. Концепція НУШ передбачає впровадження деяких інновацій у системі шкільної освіти, а саме: інтегрованого та проєктного навчання учнів задля отримання ними цілісного уявлення про світ; нової моделі оцінювання (замість звичних табелів у кінці року учні перших класів отримують Свідоцтво досягнень) [8].

У 2017 р. було ухвалено новий Закон України “Про освіту", очікуваними результатами якого стало проголошення переходу школу на трирівневу систему навчання, а саме: початкова -4 роки, вводиться 32018 р., базова середня освіта - 5 років (гімназії), вводитиметься з 2022 р., профільна середня освіта - 3 роки (ліцеї та заклади професійної середньої освіти), вводиться з 2027 р. Відтак і школа стане профільною, учень зможе обирати: навчатися в академічному ліцеї чи професійному коледжі [6].

Усі вищерозглянуті нормативні документи та законопроекти слугують підставою для візуалізації алгоритму поетапного запровадження досвіду стандартизації профільного навчання в Україні у 2011-2017 рp. XXI ст. (Рис. 1).

Зосереджуючи увагу на формуванні в учнів ключових для життя компетентностей, слід відзначити, що замість запам'ятовування фактів та понять учні набуватимуть таких компетентностей, як: вільне володіння державною

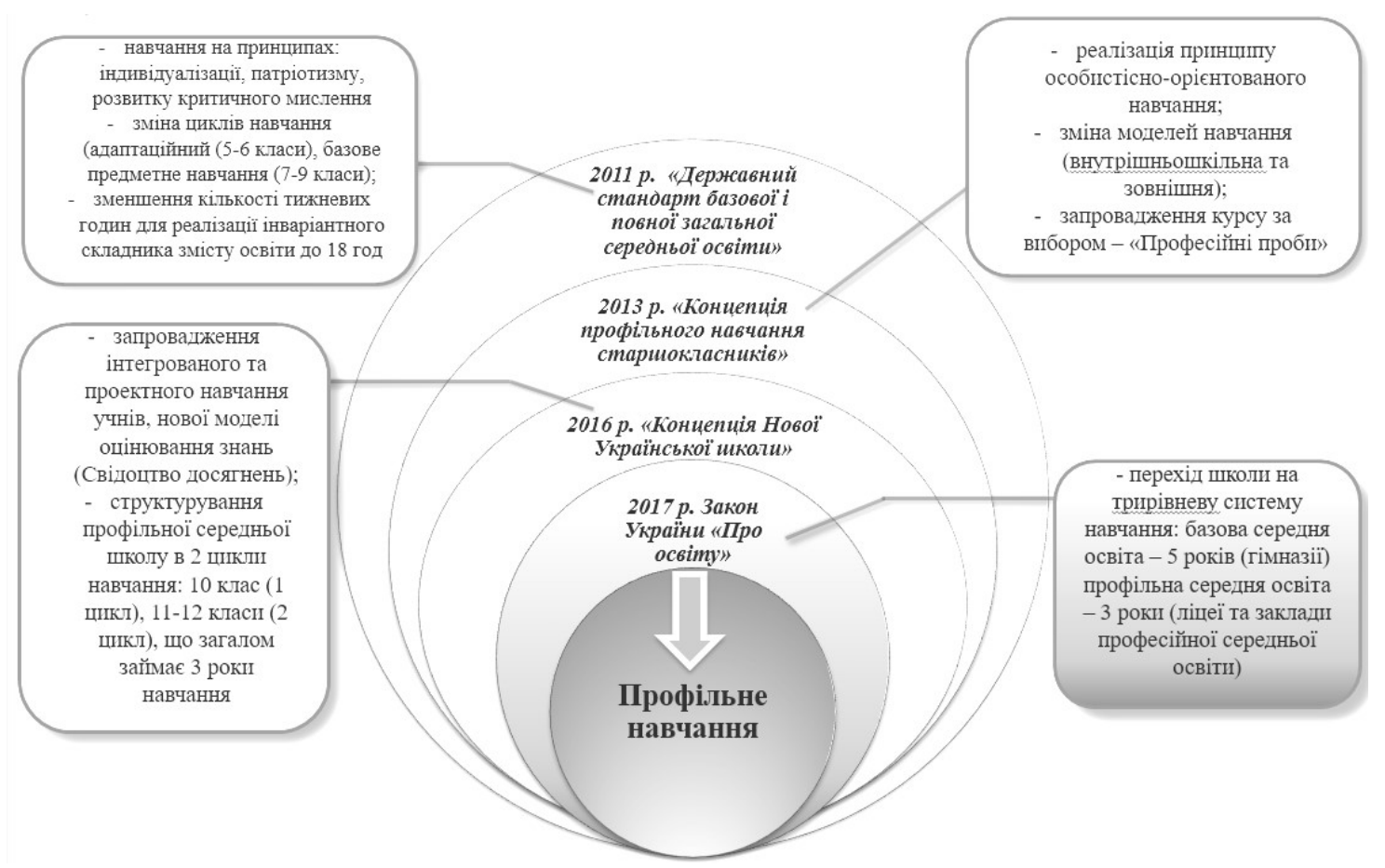

Рис. 1. Алгоритм поетапного запровадження досвіду стандартизації профільного навчання в Україні у 2011-2017 роках XXI ст. (авторська розробка) 
мовою; здатність спілкуватися рідною (у разі відмінності від державної) та іноземними мовами; математична, інноваційність, екологічна, інформаційно-комунікаційна компетентності, а також компетентності у галузі природничих наук, техніки і технологій; здатність до навчання впродовж життя; громадянські та соціальні компетентності, пов'язані з ідеями демократії, справедливості, рівності, прав людини, добробуту та здорового способу життя, з усвідомленням рівних прав і можливостей; культурна компетентність; підприємливість та фінансова грамотність $[4 ; 5 ; 10]$.

Висновки. Означене дає підстави дійти висновку, що перспективними напрямами модернізації змісту загальної середньої освіти стало прийняття і введення у дію в 2018 р. Колегією Міністерства освіти і науки "Проекту концептуальних засад реформування профільного навчання "Сучасна професійна освіта", мета якого полягає у створенні ефективної системи професійної освіти та навчання як основи економічного добробуту держави, складової сталого розвитку суспільства, запоруки професійної самореалізації та неперервного професійного розвитку особистості упродовж життя відповідно до їі інтересів та потреб економіки України.

Одним 3 перспективних стримувальних чинників розв'язання наявних проблем і формування єдиної концептуально узгодженої й науково обгрунтованої державної політики щодо розвитку профільного навчання в Україні стало також прийняття в 2019 р. Закону України “Про фахову передвищу освіту”, проєкти якого почали розроблятися лише в кінці 2017 р., який мав на меті визначення порядку, умов, форм та особливостей здобуття фахової передвищої освіти.

\section{ЛІТЕРАТУРА}

1. Васьківська Г. О., Кизенко В. І., Косянчук С. В., Барановська О. В./ Формування змісту профільного навчання: теоретико-методологічний аспект: кол. монографія. Київ, КОНВІ ПРІНТ, $2018.260 \mathrm{c}$.

2. Державний стандарт базової і повної загальної середньої освіти. URL: https:// zakon.rada.gov.ua/laws/show/1392-2011$\%$ D0\%BF\#Text

3. Загородня А. А. Профільне навчання як форма радикальної диференціації навчання. “Педагогічні науки”, м. Запоріжжя, № 2 (35). 2020. C. 17-22. DOI https://doi.org/10.26661/25224360-2020-2-02.
4. Загородня А. А. Диференціація змісту навчання у старшій школі: історико-аналітичний аспект. Молодь і ринок. 2018. Вип. № 3(158). С. 3035. DOI: https://doi.org/10.24919/2308-4634. 2018.128884 .

5. Загородня А. А. Профілізація загальної середньої освіти в контексті ідей НУШ. Науковопед. журн. “Молодь і ринок”. 2019. Вип. № 10 (177). С.126-130.

6. Закон України “Про освіту” № 2145-VIII від 28.09.2017, ВBР, 2017.

7. Каленський А. А., Лузан П. Г., Ваніна Н. М., Пащенко Т. М., Кравець С. Г., Пятничук Т. В. Стандартизація професійної освіти: теорія і практика: монографія. Житомир: “Полісся”, 2018. $256 \mathrm{c}$.

8. Концепція Нової української школи (колегія МОН від 27.10.2016) URL: https://mon.gov.ua/ storage/app/media/zagalna $\% 20$ serednya/novaukrainska-shkola-compressed.pdf

9. Концепція профільного навчання. URL: http:/ /www.uazakon.com/document/fpart86/idx86618.htm.

10. Кушнір В. М. Профільне навчання в історії розвитку вітчизняної школи (друга половина XIXХХ ст.). Монографія. Умань: Видавець “Сочінський”, 2016. 418 с.

\section{REFERENCES}

1. Vaskivska, H. O., Kyzenko, V. I., Kosianchuk, S. V. \& Baranovska, O. V./ (2018). Formuvannia zmistu profilnoho navchannia: teoretyko-metodolohichnyi aspekt [Formation of the content of profile training: theoretical and methodological aspect]. Col. monograph. Kyiv, 260 p. [in Ukrainian].

2. Derzhavnyi standart bazovoi i povnoi zahalnoi serednoi osvity (2011). [State standard of basic and complete general secondary education]. Available at: https://zakon.rada.gov.ua/laws/show/1392-2011$\% \mathrm{D} 0 \% \mathrm{BF} \# \mathrm{Text}$ [in Ukrainian].

3. Zahorodnia, A. A. (2020). Profilne navchannia yak forma radykalnoi dyferentsiatsii navchannia. [Profile education as a form of radical differentiation of education]. "Pedagogical sciences", Zaporizhzhia, No. 2 (35), pp.17-22. DOI https:// doi.org/10.26661/2522-4360-2020-2-02 [in Ukrainian].

4. Zahorodnia, A. A. (2018). Dyferentsiatsiia zmistu navchannia u starshii shkoli: istorykoanalitychnyi aspekt [Differentiation of the content of education in high school: historical and analytical aspect]. Youth \& market, Vol. 3(158), 30-35. DOI: https://doi.org/10.24919/2308-4634.2018.128884 [in Ukrainian].

5. Zahorodnia, A. A. (2019). Profilizatsiia zahalnoi serednoi osvity $\mathrm{v}$ konteksti idei NUSh [Profiling of 


\section{ПЕДАГОГІЧНІ УМОВИ ОРГАНІЗАЦІЇ ХУДОЖНЬО-КОНСТРУКТИВНОЇ ДІЯЛЬНОСТІ ДІТЕЙ ДОШКІЛЬНОГО ВІКУ В УМОВАХЗДО}

general secondary education in the context of NUS ideas]. Youth \& market, Vol. 10(177), pp.126-130. [in Ukrainian].

6. Zakon Ukrainy "Pro osvitu" (2017). [Law of Ukraine "About education"]. No. 2145-VIII 28.09.2017 [in Ukrainian].

7. Kalenskyi, A. A., Luzan, P. H., Vanina, N. M., Pashchenko, T. M., Kravets, S. H. \& Piatnychuk, T. V. (2018). Standartyzatsiia profesiinoi osvity: teoriia i praktyka; monohrafiia [Standardization of professional education: theory and practice]. Monograph. Zhytomyr, 256 p. [in Ukrainian].

8. Kontseptsiia Novoi ukrainskoi shkoly (kolehiia MON vid 27.10.2016) [Concept of the New
Ukrainian School (MES Board dated October 27, 2016)]. Available at: https://mon.gov.ua/storage/app/ media/zagalna\%20serednya/nova-ukrainska-shkolacompressed.pdf [in Ukrainian].

9. Kontseptsiia profilnoho navchannia (2013). [The concept of specialized training]. Available at: http://www.uazakon.com/document/fpart86/ idx86618.htm [in Ukrainian].

10.Kushnir, V. M. (2016). Profilne navchannia v istorii rozvytku vitchyznianoi shkoly (druha polovyna XIX-XX st.) [Profile training in the history of domestic school development (second half of the XIX-XX centuries)]. Monograph. Uman, 418 p. [in Ukrainian].

Стаття надійшла до редакції 12.08.2021

УДК 377:37.011

DOI:

Галина Борин, кандидат педагогічних наук, доцент кафедри теорії та методики дошкільної і спеціальної освіти, Прикарпатського національного університету імені Василя Стефаника

\section{ПЕДАГОГІЧНІ УМОВИ ОРГАНІЗАЦІЇ ХУДОЖНЬО-КОНСТРУКТИВНОЇ ДІЯЛЬНОСТІ ДІТЕЙ ДОШКІЛЬНОГО ВІКУ В УМОВАХ ЗДО}

У статті охарактеризовано педагогічні умови організації художньо-конструктивної діяльності педагога з дітьми дошкільного віку в умовах закладу дошкільної освіти. Основну увагу зосереджено на виокремленні та обтрунтуванні педагогічних умов у руслі означеної проблеми. Наголочено, що вони трунтуються на загальнодидактичних та специфічних принципах, характеризуються певними вимогами до проведення художньо-конструктивної діяльності з вихованиями та спрямовані на задоволення особистісних потреб та інтересів дошкільників, їхню самореалізаџію у активній творчій діяльності. Чималу увагу зосереджено на тому, щь задля обтрунтування комплексу умов щзодо організації художньо-конструктивноі діяльності дітей дошкільного віку, варто враховувати низку факторів: суперечності, які існують в царині організації художньо-конструктивної діяльності з дітьми доикільного віку; принципи організації освітнього процесу з дошкільниками; характерні особливості художньо-конструктивної діяльності дітей дошкільного віку.

Ключові слова: художньо-конструктивна діяльність; діти дошкільного віку; дошкільний заклад освіти; вихователь; педагогічні умови; особистісно-діяльнісний підхід; творчий розвиток дітей.

Лim. 14.

Halyna Boryn, Ph.D. (Pedagogy), Associate Professor, of Theory and Methods of Preschool and Special Education Department Vasyl Stefanyk Precarpathian National University

\section{PEDAGOGICAL CONDITIONS OF ORGANIZING ARTISTIC AND CONSTRUCTIVE ACTIVITY OF PRESCHOOLAGED CHILDREN IN THE CONDITIONS OF PRESCHOOL INSTITUTIONS}

The article describes the pedagogical conditions for the organization of artistic and constructive activities of a teacher with preschool children in a preschool institution. The main attention is focused on the selection and justification of pedagogical conditions of this problem. It is emphasized that they are based on general didactic and specific principles, are characterized by certain requirements for artistic and constructive activities with students and are aimed at meeting the personal needs and interests of preschoolers, their self-realization in creative activity.

Considerable attention is paid to the fact that in order to substantiate the set of conditions for the organization of artistic and constructive activities of preschool children, it is necessary to take into account a number of factors: contradictions that exist in the organization of artistic and constructive activities with preschool children; principles of organizing the educational process with preschoolers; characteristic features of artistic and constructive activity of preschool children. 